\title{
Effects of location of Norway spruce (Picea abies) stumps on their colonisation by insects in the mountains
}

\author{
Iwona Skrzecz ${ }^{1} \bowtie$, Maria Bulka², Joanna Ukalska ${ }^{3}$ \\ ${ }^{1}$ Forest Research Institute, Department of Forest Protection, Braci Leśnej 3, Sękocin Stary, 05-090 Raszyn, Poland, \\ e-mail: i.skrzecz@ibles.waw.pl \\ ${ }^{2}$ Forest District Lądek Zdrój, 57-550 Stronie Śląskie, Poland \\ ${ }^{3}$ Warsaw University of Life Sciences - SGGW, Faculty of Applied Informatics and Mathematics, Department \\ of Econometrics and Statistics, Nowoursynowska 159, 02-776 Warsaw, Poland
}

\section{Abstract}

Tree stumps provide habitat for insect assemblages, which are influenced by various factors. Among these factors, physical and chemical changes of the stumps, fungi developing in the dead wood and stump size are most often reported. However there is limited information about the abundance of insects in stumps that are located on mountains where there are different microclimatic conditions. The studies pointed at the determination whether the location of Picea abies stumps in mountains at different altitudes above sea level and on mountainsides with different sun exposure has an impact on the frequency of insects colonising them. The study was carried out in the Eastern Sudety Mountains situated in south-western Poland. The stumps were in clearcuts located at the altitudes 600-700 $\mathrm{m}$ and 900-1000 $\mathrm{m}$ above sea level and on southern and northern mountainsides. The insects were collected from $0.05 \mathrm{~m}^{2}$ of bark from each stump and identified to the family, order or species level. The numbers of insects in the stumps were modelled with the use of the Poisson distribution or the negative binomial distribution and the generalised linear models. Picea abies stumps were colonised by insects from 16 families in 3 orders (Coleoptera, Diptera, Hymenoptera) in which the Coleoptera was most frequently represented by the families Cerambycidae, Curculionidae (with the sub-family Scolytinae). In the stumps located at the elevation of 900-1000 m there were $28 \%$ more insects than in the stumps at 600-700 m. The stumps located on mountainsides with northern exposure were colonised more abundantly by Cerambycidae. Numbers of Curculionidae in the stumps were affected by altitude. Most Curculionidae were found in the stumps located at the elevation 900-1000 m above sea level. The interaction of altitude and mountainside exposure showed more insects in the stumps at higher altitude, regardless of the mountainside exposure. The results showed that the total number of insects in the stumps was influenced by their location in mountains.

\section{KeY WORDS}

mountains, altitude, exposure, insect assemblages, Coleoptera, Picea abies stump 


\section{INTRODUCTION}

Insects that colonise forest tree stumps form a range of dynamically changing assemblages. Important factors that influence entomofauna are changes in the physical and chemical properties of the stump that occur over time (Wallace 1953; von Sydow and Birgersson, 1997). These encompass changes in the microclimatic conditions of the stump (temperature and humidity) resulting from the processes of bark and wood decay. The number of insect species in the stumps decreases with progressing wood decomposition (Wiąckowski 1957). At the same time, the species of insect colonising the stumps change, from highly specialised (e.g., cambioand xylophages) towards generalist insects (e.g., ants Formicidae) (Starzyk and Sęk, 1983). As indicated by von Sydow and Birgersson (1997), in the first months after the formation of Scots pine (Pinus sylvestris L.) and Norway spruce [Picea abies (L.) Karst.] stumps, the chemical and physical processes have started, and these are followed by a decrease in stump humidity and a reduction of the number of living wood cells. Along with other changes, the concentration of ethanol declines in the resin, which is known to be an attractant for the family Curculionidae (Montgomery and Wargo 1983; Lindelöw et al. 1993; Schlyter 2004; Miller 2006).

The fungi developing in dead wood influence the insect assemblages in the stumps. The results obtained by Skrzecz $(1996,2001)$ indicated that a saprotrophic fungus Phlebiopsis gigantea (Fr.: Fr.) Jülich, which develops in P. sylvestris stumps, reduced stump colonisation by the large pine weevil Hylobius abietis (L.). Jonsell et al. (2005) found that mycelium of Fomitopsis pinicola (Sow.; Fr.) and Trichaptum abietinum (Dicks.) Ryvarden in P. abies stumps reduced the colonisation of 2-m-high stumps by many species of insects. Adverse effects of Heterobasidion spp. infections in P. abies stumps on insect species composition and the number of insects in the stumps were observed by Abrahamsson et al. (2008).

Entomofauna changeability is also determined by external microclimatic conditions. The insect species composition in the stumps left behind on clearcut areas (exposed to sunlight) differs from that in the stumps situated inside forest stands (shady sites). Starzyk (1977; Starzyk and Sęk 1983) and Kosibowicz (1987) observed that $P$. abies stumps situated within open areas were colonised by more insect species in comparison to the stumps within shady areas. Corresponding results were reported in Scandinavia, where it was observed greater species richness of saproxylic beetles in 4-m-high stumps left behind on clearcut areas than in analogous stumps localised in less-sunny spots (e.g., forest edges) (Lindhe and Lindelöw 2004; Fossestøl and SverdrupThygeson 2009).

One more important reason of the variability of insect species composition in the stumps is the size of stumps (diameter and height). Långström and Hellqvist (1985) showed a positive correlation between the diameter of $P$. silvestris stumps and the intensity of colonisation by insects, especially by the pine shoot beetle Tomicus piniperda (L.). Furthermore, Schroeder et al. (1999) found a positive correlation between the diameter of $P$. abies stumps and the intensity of colonisation by the spruce bark beetle Ips typographus (L.).

Insect assemblages in the stumps are also influenced by the height of the stump. This aspect was thoroughly researched in Sweden (Jonsell et al. 1998, 2005; Schroeder et al. 1999; Lindhe and Lindelöw 2004; Abrahamsson and Lindbladh 2006; Lindbladh and Abrahamsson 2008), where it is now recommended to leave high (above $0.5 \mathrm{~m}$ ) stumps on clearcut areas because these provide habitat for many rare insect species.

As described above, investigations have been carried out on the various effects of factors such as wood and bark decomposition, sunlight availability and stump size on insect assemblages. However, the effects of different external microclimatic conditions on entomofauna in the stumps located on southern and northern mountainsides with different sunlight availability have not been reported yet. Furthermore, there is little information on insect assemblages in P. abies stumps localised at different mountain altitudes above sea level (a.s.1.). The lack of such information led to the studies in which the following hypotheses were adopted:

- the altitude a.s.l. affects insect assemblages in $P$. abies stumps, and due to more favourable weather conditions, the stumps located at lower altitudes a.s.l. are more intensively colonised by insects than those located at higher altitudes;

- the localisation of $P$. abies stumps on different mountainsides has an impact on the number of insects, and the increased sun exposure of stumps on southern mountainsides encourages their colonisation by insects; 
- the interaction between mountainsides and altitude a.s.l. causes the most intense colonisation of stumps located on the lower altitudes and on southern mountainsides.

The present study was undertaken to determine whether diverse conditions of stump sites localised on altered mountainsides and altitudes a.s.l. influenced insect assemblages in fresh P. abies stumps.

\section{Material AND MethodS}

\section{Study area and insect sampling}

The study was carried out in forest stands managed by State Forests in the Eastern Sudety Mountains situated in south-western Poland (50²0’35' N, 16 52'43'”E) (Fig. 1). The experimental region was located $450-1425 \mathrm{~m}$ above sea level where the mountain climatic conditions show distinct zonation depending upon the altitude above sea level (Malachowska et al. 2007). The average annual temperature is $6.5^{\circ} \mathrm{C}$ at an altitude of $500 \mathrm{~m}$ a.s.l. and $2.4^{\circ} \mathrm{C}$ at $>1100 \mathrm{~m}$ a.s.l. The vegetative growing season lasts 195-200 days at $500 \mathrm{~m}$ a.s.l., 190-195 days at an altitude of $700 \mathrm{~m}$ a.s.l. and 150 days at $1200 \mathrm{~m}$ a.s.l. The average annual precipitation is from $700 \mathrm{~mm}$ (500 m a.s.1.) to more than $1200 \mathrm{~mm}$ (altitudes above $1250 \mathrm{~m}$ ). The snow cover remains from 105-110 days at the elevation of 500-600 m a.s.l. to approximately 180 days at $1300 \mathrm{~m}$ a.s.l. Southern and south-western winds dominate and cause serious damage in the forests.

The observations were conducted in the years 2003-2005 in areas of clearcuts located at 2 altitudes a.s.l. and formed after the harvest of 70 to 100 -year-old $P$. abies stands (more than $85 \%$ spruce trees) that had been damaged by wind. The observed clearcuts

Figure 1. A map of Eastern Sudety Mountains in Poland with location of experimental areas. The numbers indicate altitude above sea level, the black triangles the position of experimental plots
(3-5 ha) were situated at $600-700 \mathrm{~m}$ a.s.l. and $900-1000$ $\mathrm{m}$ a.s.l. The high-diameter timber (e.g. the trunks, treetops) was removed from these areas, while the small logging slash (wood debris) remained because its removal is difficult and not economical in high mountain areas.

All clearcuts were surrounded by $P$. abies stands ( $>85 \%$ spruce trees) that were more than 60 years old and the distance between them was greater than $500 \mathrm{~m}$. On the clearcuts, there were centrally located $(>15 \mathrm{~m}$ from the forest edge) experimental plots $0.06-0.09$ ha $(25-30 \times 25-30 \mathrm{~m})$ in size. Twelve research plots were established each year of observation:

- 6 research plots at an altitude of 600-700 m a.s.l., of which 3 plots were situated on mountainsides with a northern exposure and 3 on mountainsides with a southern exposure,

- 6 research plots at an altitude of 900-1000 m a.s.l., of which 3 plots were situated on the mountainside with a northern exposure and 3 on mountainsides with a southern exposure.

During 3 years of observations, 36 research plots were established in total (18 at $600-700 \mathrm{~m}$ and 18 at 900-1000 m a.s.1.). Within each plot, 10 P. abies stumps were observed. A total of 360 stumps were observed. Only man-made and fresh stumps (8-12 months old) were selected for further observations. These were stumps that had been created in either the last four

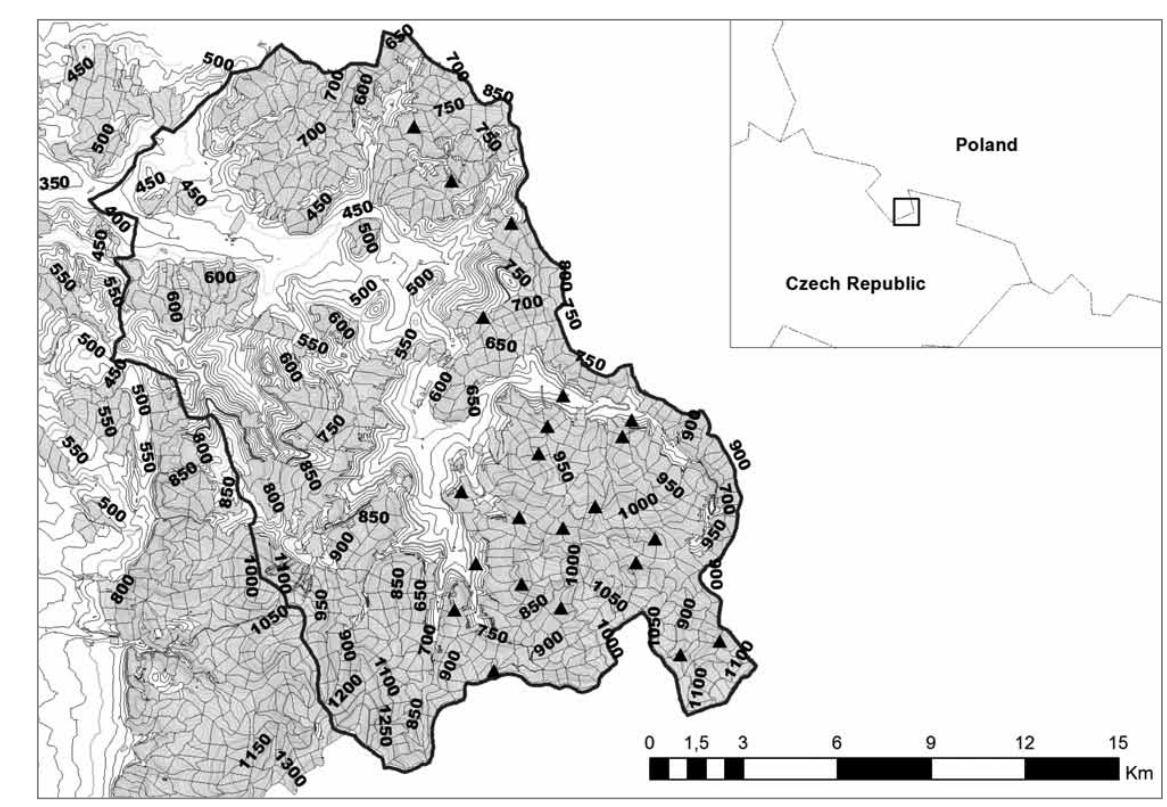


months of the previous year or the first 4 months of the current year of investigations. The selected stumps were uniform in size. Their diameter was between 45 and $72 \mathrm{~cm}(57.1 \mathrm{~cm} ; 16.3 \%$, mean; coefficient of variation), and the height was between 25 and $52 \mathrm{~cm}(36.2 \mathrm{~cm}$; 19.7\%). In September or October of the study years, 5 bark samples were collected from 10 stumps on each research plot (sections $10 \times 10 \mathrm{~cm}$, in total $0.05 \mathrm{~m}^{2}$ of bark/stump) (Safranyik and Linton 1999). The samples were taken from aboveground stump parts around the root neck and from coarse roots distributed around the stem base. Each sample included any insect material found in and under the collected bark. Next, bark samples were transported to the laboratory to extract all the insects. The insect culture was carried out in photoeclectors (securely covered cardboard boxes $50 \times 40 \times 30 \mathrm{~cm}$ ). Additionally, a container filled with water and covered with mesh was placed in each photoeclector. In each box, a glass tube was fixed for the collection of emerging adults. The culture was carried out at $22 \pm 2^{\circ} \mathrm{C}$ and $60 \%$ humidity for 4 weeks. Then, all insect larvae, pupae and adults found in the samples were identified to the family, genus or species level according to the keys for the determination of Polish insects.

\section{Statistics}

The number of insects in the stumps was treated as count data, which were modelled with the use of the Poisson distribution or the negative binomial distribution. Accordingly, the generalised linear models GzLM (Nelder and Weddenburn 1972; McCullagh and Nelder 1989) were applied in the statistical analyses. The influence of the explanatory variables, such as stump altitude and exposure, on the response variable was assessed. The analyses were carried out on the total number of insects and separate calculations were also performed on various insect taxonomic groups that were identified (Cerambycidae, Curculionidae, Scolytinae, other insects). For each group, the fixed model was applied:

$$
\log \left(\lambda_{i j k}\right)=a_{i}+m_{j}+a m_{i j}+y_{k}
$$

where:

$$
\begin{aligned}
& \log \left(\lambda_{i j k}\right) \text { - the canonical link function, } \\
& \lambda_{i j k} \quad \text { the mean count for the } i j k^{\text {th }} \text { altitude - moun- } \\
& \text { tainside-year combination, } \\
& a_{i} \quad-\text { the } i^{\text {th }} \text { altitude effect }(i=1,2), \\
& m_{j} \quad-\text { the } j^{\text {th }} \text { mountainside effect }(j=1,2),
\end{aligned}
$$

$a m_{i j} \quad$ - the $i j^{\text {th }}$ altitude-mountainside interaction effect,

$y_{k} \quad-$ the $k^{\text {th }}$ year effect $(k=1,2,3)$.

The year of the study was included in the model as a covariate to take into account the possible variation resulting from the impact of weather conditions.

Due to the possibility of overdispersion (McCullagh and Nelder 1989), and therefore the possibility of the incorrect application of the Poisson model, the goodness-of-fit statistic (Stokes et al. 2000; Littel et al. 2002) was used in the analyses. The evidence of overdispersion was tested with the likelihood ratio test based on the Poisson distribution and the negative binomial distribution (Cameron and Trivedi 1998). In cases of overdispersion, the analysis of the model for a given insect group was carried out with the use of the negative binomial distribution with $\log (1)$ as the canonical link. Otherwise, the Poisson distribution was applied. Details concerning the selection of the model for the selected groups are reported in Table 1. The significance of the model effects was tested with the likelihood ratio chisquared statistic for the type 3 analysis. The contrast analysis was applied for comprehensive comparisons of significant model effects.

Table 1. Assessment of model fit for two considered distributions

\begin{tabular}{|l|c|c|c|}
\hline \multirow{2}{*}{} & \multicolumn{2}{|c|}{ Deviance/df } & \multirow{2}{*}{\begin{tabular}{c} 
Distribution \\
used \\
\cline { 2 - 3 }
\end{tabular}} \\
\cline { 2 - 3 } & $\begin{array}{c}\text { negative } \\
\text { binomial }\end{array}$ & poisson & NB \\
\hline All insects & 1.2032 & 4.1129 & NB \\
\hline Cerambycidae & 1.1253 & 3.6617 & NB \\
\hline Curculionidae & 0.8495 & 3.4782 & Poisson \\
\hline Scolytinae & 0.2156 & 1.8404 & Poisson \\
\hline Other insects & 0.5627 & 1.5007 & \\
\hline
\end{tabular}

In case of the numbers of all insects, Cerambycidae and Curculionidae (excluding Scolytinae) found in the bark samples $\left(0.05 \mathrm{~m}^{2}\right)$, the values of the deviance in the model based on the Poisson distribution were much higher than the value of 1 . This indicated great overdyspersion and consequently the negative binominal distribution was applied for these insect groups. The Poisson distribution in which statistical values were corrected with regard to overdispertion (Littel et al. 2002) was applied for Scolytinae and the group of other insects.

The analyses were carried out using SAS 9.2 software (SAS Institute 2008). The procedure GENMOD (Stokes et al. 2000; Littell et al. 2002) was followed. 


\section{Results}

\section{The total number of insects in $P$. abies stumps}

The results indicated insect colonisation in all 360 stumps that were examined during three years of observations. In total, there were 1930 insects collected (95\% in the larval stage) (Tab. 2). On average, $5.36 \pm 0.28$ insects (mean $\pm \mathrm{SE}$ ) were found in the bark samples collected from each stump $\left(0.05 \mathrm{~m}^{2} / \mathrm{stump}\right)$.

Table 2. The species composition and abundance of insects in the stumps

\begin{tabular}{|c|c|c|}
\hline Name & 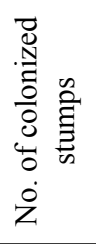 & 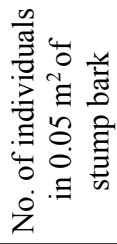 \\
\hline 1 & 2 & 3 \\
\hline \multicolumn{3}{|c|}{ COLEOPTERA } \\
\hline \multicolumn{3}{|l|}{ Cerambycidae } \\
\hline Arhopalus rusticus (L.) & 8 & 24 \\
\hline Corymbia rubra (L.) & 1 & 3 \\
\hline Obrium brunneum (Fabr.) & 4 & 16 \\
\hline Oxymirus cursor (L.) & 5 & 5 \\
\hline Rhagium inquisitor (L.) & 84 & 243 \\
\hline Tetropium castaneum (L.) & 293 & 736 \\
\hline \multicolumn{3}{|l|}{ Cleridae } \\
\hline Thanasimus formicarius (L.) & 7 & 12 \\
\hline \multicolumn{3}{|l|}{ Curculionidae } \\
\hline Dryocoetes autographus (Ratz.) & 15 & 35 \\
\hline Hylastes ater (Payk.) & 18 & 23 \\
\hline Hylastes cunicularius (Er.) & 29 & 35 \\
\hline Hylobius abietis (L.) & 217 & 579 \\
\hline Ips typographus (L.) & 20 & 65 \\
\hline \multicolumn{3}{|l|}{ Elateridae } \\
\hline Ampedus pomorum (Herbst.) & 13 & 22 \\
\hline Hemicrepidius sp. & 9 & 16 \\
\hline Melanotus spp. & 3 & 4 \\
\hline \multicolumn{3}{|l|}{ Lymexylonidae } \\
\hline Hylecoetus dermestoides (L.) & 1 & 1 \\
\hline \multicolumn{3}{|l|}{ Monotomidae } \\
\hline Rhizophagus dispar (Payk.) & 5 & 7 \\
\hline Rhizophagus ferrugineus (Payk.) & 1 & 1 \\
\hline
\end{tabular}

\begin{tabular}{|c|c|c|}
\hline 1 & 2 & 3 \\
\hline \multicolumn{3}{|l|}{ Nitidulidae } \\
\hline Glischrochilus quadripustulatus (L.) & 2 & 6 \\
\hline \multicolumn{3}{|l|}{ Oedemeridae } \\
\hline Calopus serraticornis (L.) & 2 & 4 \\
\hline \multicolumn{3}{|l|}{ Pyrochroidae } \\
\hline Schizotus pectinicornis (L.) & 2 & 6 \\
\hline \multicolumn{3}{|l|}{ Staphylinidae } \\
\hline Atheta fungi (Grav.) & 1 & 1 \\
\hline Nudobius lentus (Grav.) & 3 & 18 \\
\hline Quedius punctatelius (Herr.) & 1 & 1 \\
\hline Philonthus decorum (Grav.) & 1 & 3 \\
\hline \multicolumn{3}{|l|}{ DIPTERA } \\
\hline \multicolumn{3}{|l|}{ Asilidae } \\
\hline Laphria flava (L.) & 1 & 3 \\
\hline Laphria gibbosa $(\mathrm{L})$. & 1 & 2 \\
\hline Empididae & 1 & 2 \\
\hline Muscidae & 9 & 25 \\
\hline Rhagionidae & 7 & 19 \\
\hline Syrphidae & 1 & 4 \\
\hline Tachinidae & 1 & 2 \\
\hline Therevidae & 1 & 2 \\
\hline Xylophagidae & 2 & 5 \\
\hline
\end{tabular}

The family Cerambycidae (53.2\% of all insects collected) was the most abundant and in the bark samples $\left(0.05 \mathrm{~m}^{2}\right)$ from one stump, there were $2.85 \pm 0.18$ insects on average. The family Curculionidae, excluding the subfamily Scolytinae (30.0\%), was the next most abundant group, represented by an average of $1.64 \pm 0.16$ insects in $0.05 \mathrm{~m}^{2}$ of bark. The subfamily Scolytinae was the third most abundant group and included $8.2 \%$ of the insects that were collected (average $0.45 \pm 0.11$ specimens $/ 0.05 \mathrm{~m}^{2}$ of bark). The remaining $8.6 \%$ of collected entomofauna (on average $0.51 \pm 1.46$ specimens $/ 0.05 \mathrm{~m}^{2}$ of bark) belonged to 16 insect families. These insects were analysed together, forming the group of other insects. The group of other insects was represented most numerously by Elateridae, and 2 families belonging to Diptera: Muscidae and Rhagionidae.

A comparison of the number of all insects found in the bark samples $\left(0.05 \mathrm{~m}^{2} / \mathrm{stump}\right)$ collected from the 180 stumps at $600-700 \mathrm{~m}$ and at $900-1000 \mathrm{~m}$ a.s.l. indicated a statistically significant increase of the total insect number in the stumps situated at a higher altitude by $37 \%$ 
(Tab. 3, Fig. 2). The total number of insects found in the bark samples $\left(0.05 \mathrm{~m}^{2}\right)$ collected from the 180 stumps situated on the mountainsides with a northern exposure was $24 \%$ higher when compared with the bark samples taken from the 180 stumps situated on mountainsides with a southern exposure. These differences were statistically significant (Tab. 3). The effect of altitude-exposure interaction showed the same intensity of stump colonisation by insects on the northern exposure regardless of the altitude (Tab. 3, Fig. 3). However, the total insect number was significantly higher in the stumps situated on mountainsides with a southern exposure at an altitude $900-1000 \mathrm{~m}$ and was similar to the number of insects found in the stumps with a northern exposure.

Table 3. The Chi-squared values for the type 3 analysis and the significance of the models' effects for the insects tested

\begin{tabular}{|c|c|c|c|}
\hline & $\mathrm{DF}$ & $c^{2}$ & $\mathrm{p}$ \\
\hline \multicolumn{4}{|l|}{ All insects } \\
\hline altitude (a.s.1.) & 1 & 16.9 & $<0.001$ \\
\hline mountainside exposition & 1 & 5.93 & 0.015 \\
\hline altitude-exposition interaction & 1 & 5.53 & 0.019 \\
\hline year & 2 & 46.06 & $<0.001$ \\
\hline \multicolumn{4}{|l|}{ Cerambycidae } \\
\hline altitude (a.s.1.) & 1 & 0.67 & 0.414 \\
\hline mountainside exposition & 1 & 6.95 & 0.008 \\
\hline altitude-exposition interaction & 1 & 0.01 & 0.942 \\
\hline year & 2 & 9.58 & 0.008 \\
\hline \multicolumn{4}{|l|}{ Curculionidae (excl. Scolytinae) } \\
\hline altitude (a.s.1.) & 1 & 24.37 & $<0.001$ \\
\hline mountainside exposition & 1 & 1.92 & 0.166 \\
\hline altitude-exposition interaction & 1 & 3.84 & 0.050 \\
\hline year & 2 & 29.46 & $<0.001$ \\
\hline \multicolumn{4}{|l|}{ Scolytinae } \\
\hline altitude (a.s.1.) & 1 & 24.85 & $<0.001$ \\
\hline mountainside exposition & 1 & 0.45 & 0.504 \\
\hline altitude-exposition interaction & 1 & 22.11 & $<0.001$ \\
\hline year & 2 & 81.81 & $<0.001$ \\
\hline \multicolumn{4}{|l|}{ Other insects } \\
\hline altitude (a.s.1.) & 1 & 3.59 & 0.058 \\
\hline mountainside exposition & 1 & 0.53 & 0.466 \\
\hline altitude-exposition interaction & 1 & 0.16 & 0.690 \\
\hline year & 2 & 25.06 & $<0.001$ \\
\hline
\end{tabular}

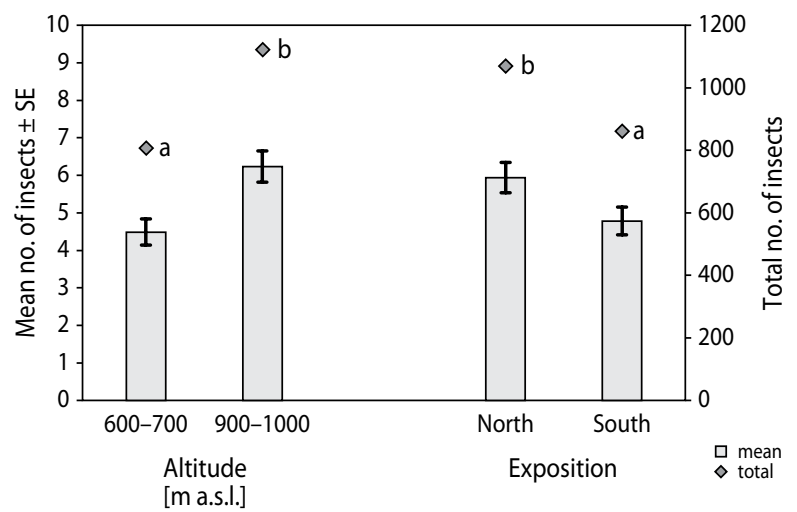

Figure 2. The total number and the mean values (with standard errors) of all insects in $0.05 \mathrm{~m}^{2}$ bark samples taken from $P$. abies stumps and the effects of stump altitude and mountainside exposure on insect numbers; different letters show significant differences at $p \leq 0.05$

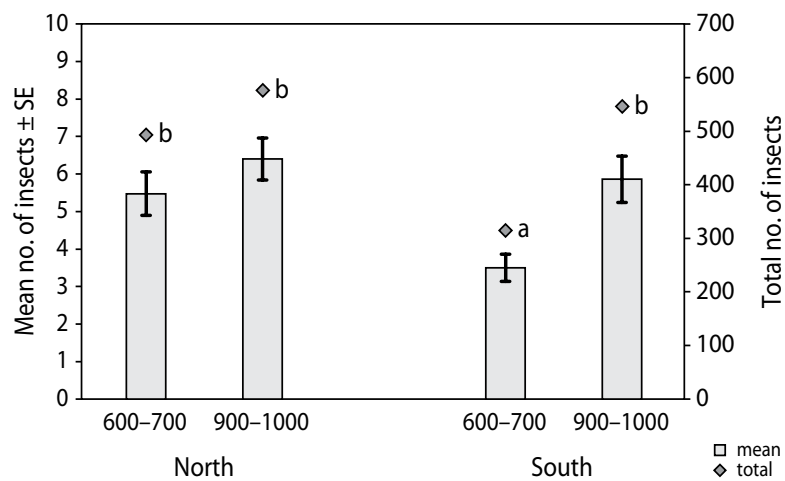

Figure 3. The effect of altitude-exposure interaction on all insect numbers (total and mean values with standard errors) in $0.05 \mathrm{~m}^{2}$ bark samples taken from $P$. abies stumps; different letters show significant differences at $p \leq 0.05$

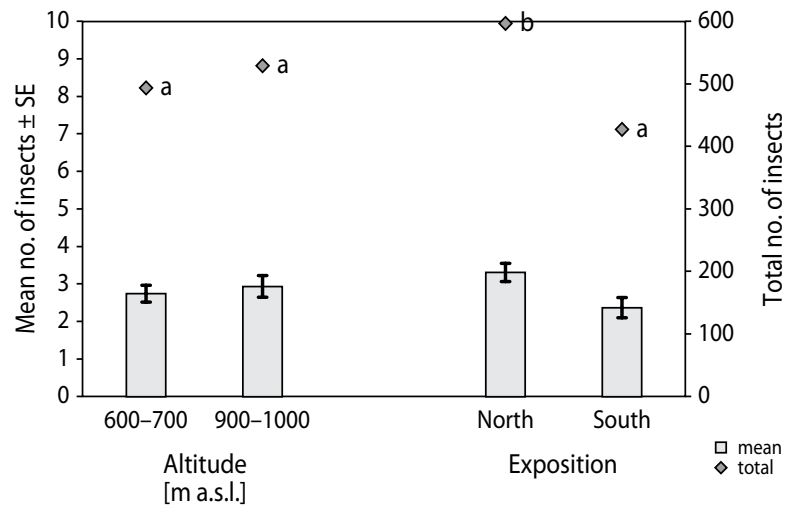

Figure 4. The total number and the mean values (with standard errors) of Cerambycidae in $0.05 \mathrm{~m}^{2}$ bark samples taken from $P$. abies stumps and effects of stump altitude and mountainside exposure on insect numbers; different letters show significant differences at $p \leq 0.05$ 


\section{Cerambycidae}

Statistical differences in Cerambycidae numbers were observed only in stumps situated on the mountainsides with different exposures (Tab. 3), in which case 39\% more insects were found in the stumps with northern exposure (Fig. 4, 5).

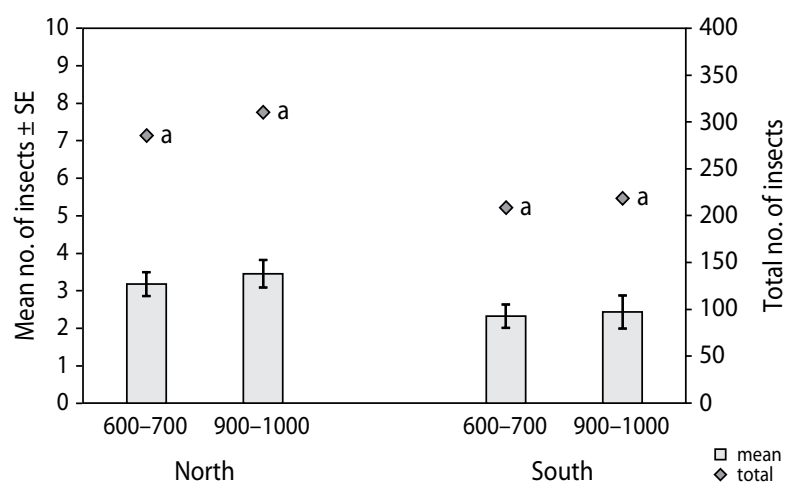

Figure 5. The effect of altitude-exposure interaction on Cerambycidae numbers (total and mean values with standard errors) in $0.05 \mathrm{~m}^{2}$ bark samples taken from $P$. abies stumps; different letters show significant differences at $p \leq 0.05$

\section{Curculionidae (excl. Scolytinae)}

Significant differences were observed between numbers of Curculionidae (excl. Scolytinae) depending on stump altitude; more than twice specimens were found in the stumps at $900-1000 \mathrm{~m}$ than at $600-700 \mathrm{~m}$ a.s.l. (Tab. 3, Fig. 6). Effect of altitude-exposure interaction showed

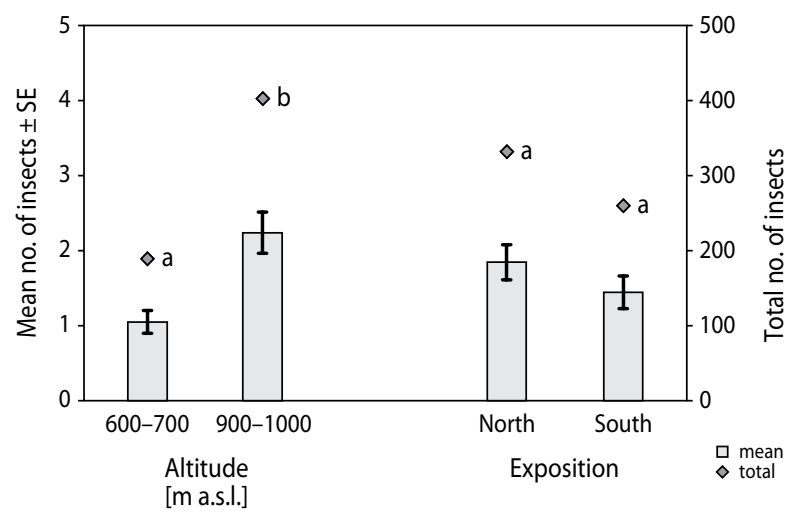

Figure 6. The total number and the mean values (with standard errors) of Curculionidae (excl. Scolytinae) in $0.05 \mathrm{~m}^{2}$ bark samples taken from $P$. abies stumps and the effects of stump altitude and mountainside exposure on insect numbers; different letters show significant differences at $p \leq 0.05$ that these differences occurred regardless of mountainside exposure (Tab. 3, Fig. 7). At the same time, at altitude 600-700 m these insects were more numerous in the stumps situated on the mountainsides with northern exposure.

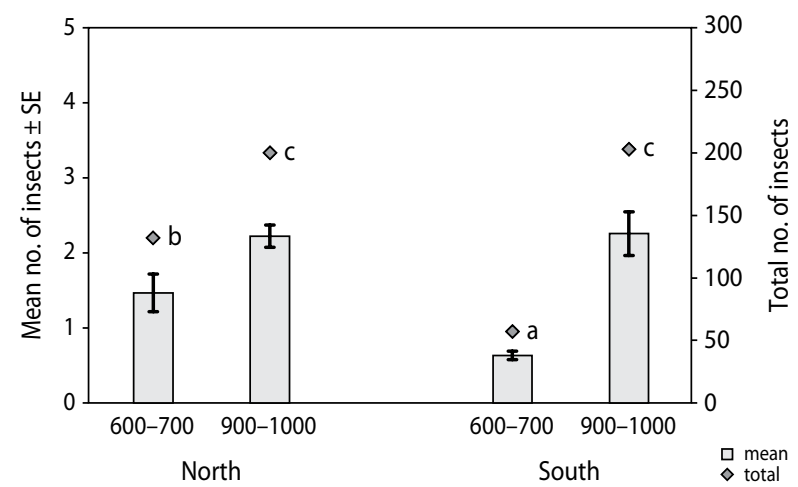

Figure 7. The effect of altitude-exposure interaction on Curculionidae (excl. Scolytinae) numbers (total and mean values with standard errors) in $0.05 \mathrm{~m}^{2}$ bark samples taken from $P$. abies stumps; different letters show significant differences at $p \leq 0.05$

\section{Scolytinae}

Comparison of Scolytinae numbers indicated significantly three times more specimens in the stumps located at higher altitude (Tab. 3, Fig. 8). Although more insects were found in the stumps with southern exposure, these differences were statistically insignificant when compared with the stumps situated on the mountain-

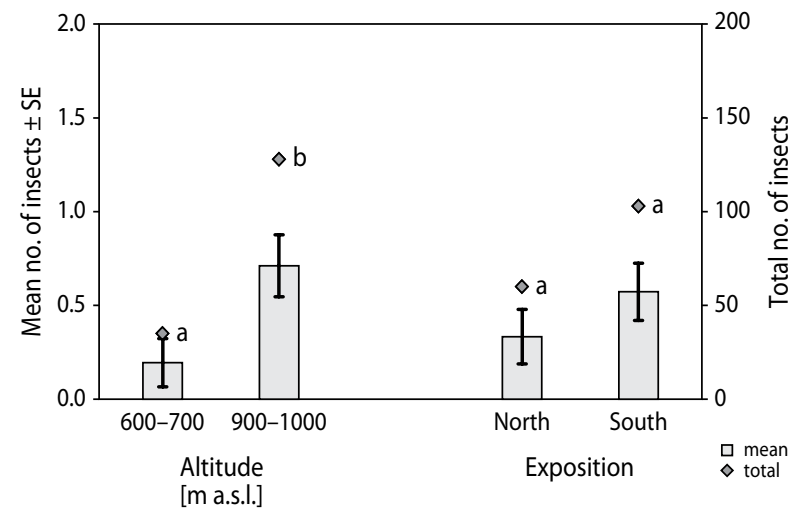

Figure 8. The total number and the mean values (with standard errors) of Scolytinae in $0.05 \mathrm{~m}^{2}$ bark samples taken from $P$. abies stumps and the effects of stump altitude and mountainside exposure on insect numbers; different letters show significant differences at $p \leq 0.05$ 
sides with northern exposure (Fig. 8). A statistically significant effect of altitude-exposure interaction showed that most Scolytinae colonised the stumps situated on the mountainsides with southern exposure at the elevation of 900-1000 m a.s.l. (Tab. 3, Fig. 9). The smallest numbers of this group were observed in the stumps with southern exposure situated at 600-700 m a.s.l. Scolytinae numbers in the stumps on the mountainsides with northern exposure were similar at both altitudes.

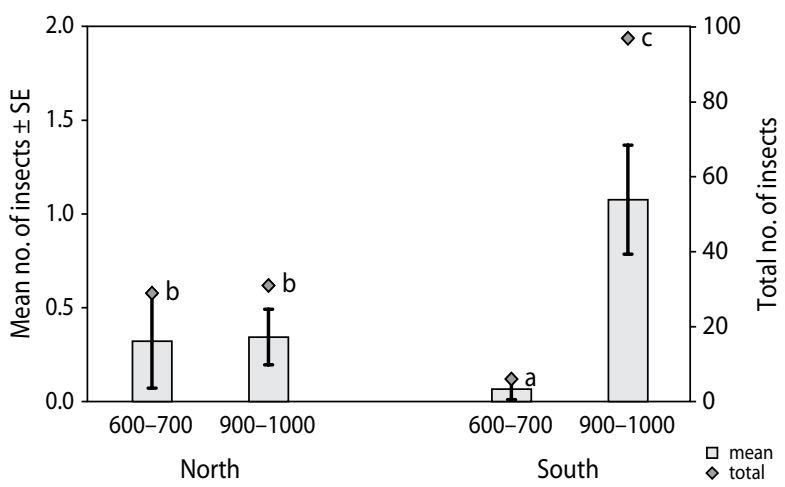

Figure 9. The effect of altitude-exposure interaction on Scolytinae numbers (total and mean values with standard errors) in $0.05 \mathrm{~m}^{2}$ bark samples taken from $P$. abies stumps; different letters show significant differences at $p \leq 0.05$

\section{Other insects}

The group of other insects indicated higher numbers (by $31 \%$ ) in the stumps at lower altitude (Fig. 10). This difference was close to statistical significance $(p=0.058$,

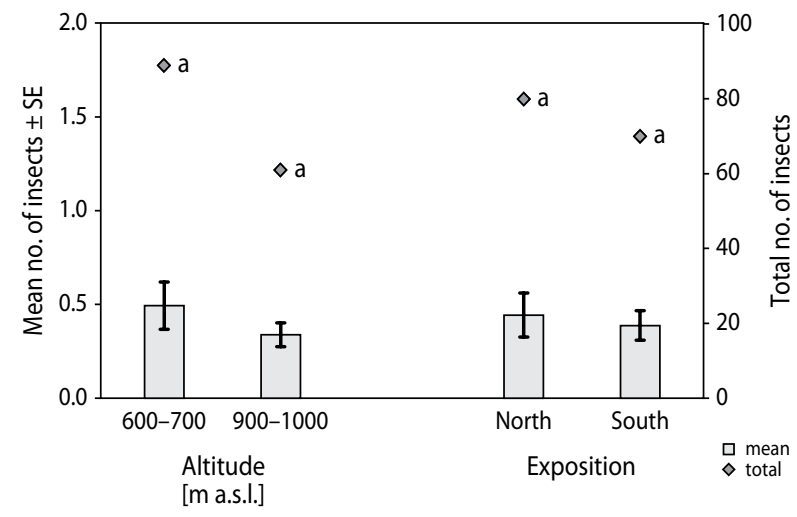

Figure 10. The total number and the mean values (with standard errors) of other insects in $0.05 \mathrm{~m}^{2}$ bark samples taken from $P$. abies stumps and the effects of stump altitude and mountainside exposure on insect numbers; different letters show significant differences at $p \leq 0.05$
Tab. 3). There were no differences between numbers of other insects in the stumps located on both exposures (Fig. 10). Also the altitude-exposure interaction did not affect the numbers of other insects in observed stumps (Fig. 11).

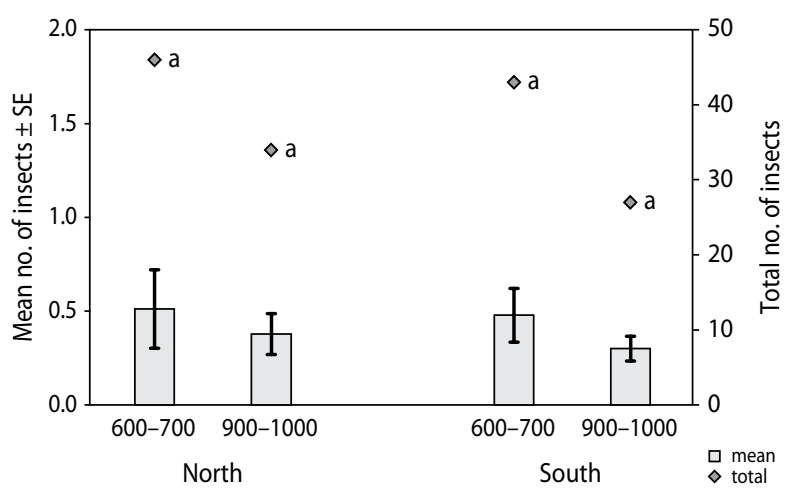

Figure 11. Effect of altitude-exposure interaction on other insect numbers (total and mean values with standard errors) in $0.05 \mathrm{~m}^{2}$ bark samples taken from $P$. abies stumps; different letters show significant differences at $p \leq 0.05$

\section{Discussion}

Picea abies stumps situated in the Eastern Sudety Mts. provided habitat for numerous insect species, mainly from the order Coleoptera. In the research material that was collected, the family Cerambycidae and Curculiondae dominated, followed by the considerably abundant sub-family Scolytinae. These results confirm wellknown observations that conifer stumps are the shelter or place of development for many beetles from the above families (Day et al. 2004; Evans et al. 2004; Sauvard 2004). Other beetle families were represented by fewer specimens. The order Diptera was the next most abundant group of insects that were observed. Many groups of Diptera have larvae that develop in association with the dead wood of stumps (McLean 2000; Rotheray et al. 2001). In most cases they are saprophages, though some are predators on other larvae. Other families were considerably less numerous. In this last group, the majority of specimens found belonged to Elateridae, Muscidae and Rhagionidae.

The number of insects in the stumps was influenced by the altitude a.s.l. More insects were observed in the stumps at an altitude of 900-1000 $\mathrm{m}$ than in the stumps 
at $600-700 \mathrm{~m}$ a.s.l. Similar results were obtained by Idris et al. (2002) who studying the insect assemblages at altitudes up to 1350 a.s.l. found the highest numbers of Coleopterans in pitfall traps located at 1100-1350 m a.s.l. Another cause for increased numbers of insects at higher altitudes may be a migration of insects by climate warming. Warmer than average temperatures, particularly during summer, appeared to shorten the time for beetles to complete development. Also levels of parasitism and predation tend to decline with increasing altitude. Such conclusions were reached by Gibson et al. (2008) investigating the migration of Dendroctonus ponderosae and by Hoiss et al. (2012) studying the impact of altitude on bee communities. On the other hands, Hodkinson (2005) said that different species vary in their population response to altitude showing increasing, declining or no altitudinal trends in abundance. He also maintained that population densities of phytophagous insects at any altitude are ultimately determined by the trophic interaction between the host plant and the insect. The host plants at the highest altitudes are more exposed to the abiotic stressors such as lower mean temperatures, shorter growing season, poorer soils and increasing strong winds causing them more susceptible to insect attacks (Kronfuss and Havranek 1999). Lower retention capacity and lower nutrient status affect resource allocation within the plants by increasing root to shoot biomass ration, thereby increasing the potential impact of root-feeding or root-developing insects (Brown and Gange 1990; Oleksyn et al. 1998; Kronfuss and Havranek 1999). Weiss et al. (1988) concluded that local topography, by creating significant microclimatic variation, may have a major modifying effect on the distribution of insects, by producing effects over short vertical distances that override the more general altitudinal trends. The authors of presented studies consider also an influence of lower temperature on higher altitudes. It can prevents the stumps before drying, which makes them attractive to insects for longer time due to volatiles emitted from the resin which are well known attractants for bark and wood boring beetles (Montgomery and Wargo 1983; Lindelöw et al. 1993; Schlyter 2004; Miller 2006).

The location of the stumps on the mountainsides affected the insect assemblages that were observed. The results showed more insects in stumps on mountainsides with a northern exposure, compared to the lower rate of insect abundance in the stumps located on southern mountains with higher sunlight availability. The effect of sunlight on insects in tree stumps has been investigated by several authors (Starzyk and Sek 1983; Kosibowicz 1987; Linde and Lindelöw 2004). However, those studies most often compared entomofauna in tree stumps within open, sunny areas (clearcuts, windfallen or fire damaged stands) with those situated under trees (shady). Starzyk and Sek (1983) and Kosibowicz (1987) indicated that the colonisation of cambio- and xylophagous insects in $P$. abies stumps was affected by the degree of sunlight availability and showed higher numbers of insects in the stumps within open areas (wind-fallen stands) compared with the stumps located in shady stand sites. Similar results were obtained by Lindhe and Lindelöw (2004), who observed a 50\% increase in the numbers of saproxylic beetle species in the snags of spruce (P. abies), oak (Quercus robur), poplar (Populus tremula) and beech (Betula pendula) when compared with the stumps in shady stand sites. In the present study, all observed stumps were situated within open areas and exposed to the effects of wind, which would be even more pronounced on southern mountainsides where the additional sunlight could enhance the drying processes in the stumps. This could be the reason for the reduction of stump attractiveness for insects. Accordingly, the higher moisture in the stumps situated on the mountainsides with a northern exposure may be the reason for their prolonged attractiveness for many insect species. This explanation would provide additional support for the results obtained by Starzyk and Sek (1983), who found the most numerous assemblages of insects in stumps with high humidity compared with those with low humidity.

The interaction of altitude and mountainside exposure affected the total number of insects in all stumps that were observed. The highest intensity of insect colonisation was observed in the stumps at an altitude of 900-1000 m a.s.l., regardless of mountainside exposure. Caroll et al. (2003) observed similar relations in the case of $D$. ponderosae which expanded its range into more northern mountainsides and higher altitudes - areas previously thought to be climatically unsuitable for beetle outbreaks. They think that the rapid colonization by beetles of these areas is related to the climate warming which allow the insects to further expand its range northward toward higher altitudes. 
The number of Cerambycidae was affected by the different site conditions resulting from stumps that were situated on southern or northern mountainsides. In the present study, lower numbers of Cerambycidae larvae were found in the stumps on southern mountainsides. Presumably, this effect was caused by the availability of less suitable habitat for these insects being provided when the stumps dried out when exposed to the sun. In addition, the snow cover lasts longer on the northern mountainsides. The presence of a thermally protective snow cover can protect insects from extreme air temperatures making the stumps on the northern mountainsides more suitable for insect development (Coulson et al. 1995). The altitude of a stump's location did not affect the level of stump colonisation by Cerambycidae. However, Starzyk and Szafraniec (1989) obtained different results while observing longhorn beetles in the Western Beskidy Mts. The authors showed that insect population numbers, as well as the species numbers, decreased with higher altitudes. A similar relationship was observed by Starzyk et al. (1991) in the Gorce Mts., where at $700 \mathrm{~m}$ a.s.l. they found 51 Cerambycidae species and only 18 species at altitudes $\geq 1200 \mathrm{~m}$ a.s.l. At the same time, the numbers of longhorn beetles were reduced by $73 \%$ at higher altitudes. According to Starzyk et al. (1991), the spatial distribution of Cerambycidae was a result of various abiotic factors with limiting effects on the occurrence and population numbers of certain Cerambycidae species at higher altitudes.

The number of Curculionidae (excl. Scolytinae) in P. abies stumps was affected by the stump altitude. Lower numbers of weevils were observed in the stumps at $600-700 \mathrm{~m}$ a.s.1 when compared with the stumps at 900-1000 $\mathrm{m}$ a.s.1. Many observations indicated that assemblages of Curculionidae (excl. Scolytinae) in conifer stumps were mainly of the genus Hylobius that is represented by weevils $H$. abietis and Hylobius pinastri. These species are known to be extremely pervasive pests of reforested areas (Wallace 1953; Więckowski 1957; Elton 1964; Day et al. 2004). The results of studies conducted in the Polish mountains confirm that $\mathrm{H}$. abietis belongs to the most abundant cambio-xylophagous species colonising P. abies stumps (Starzyk and Sek 1983). This insect develops in the stumps of conifer trees that were killed by wind, snow, fire or insects; and in wood debris, such as fallen branches and tree tops ly- ing on the ground (Leather et al. 1999; Day et al. 2004). It is therefore assumed that the slash that is retained on clearcuts at higher altitudes may lead to the increased population of weevils in these areas.

Stumps that were situated on different mountainsides and had a resulting difference in sunlight intensity had no effect on the number of weevils in the stumps. Similar results were obtained by Bejer-Petersen (1975), who found no significant differences in the numbers of $H$. abietis larvae in conifer stumps in clearcuts and partly cut areas. Fossestøl and Sverdrup-Thygeson (2009) also observed similar numbers of H. abietis in high stumps located in the forest edge and in clearcuts. Contrasting results were obtained by Bake and Lekander (1965), who found higher numbers of $H$. abietis emerging from conifer billets in sunny areas than in shaded ones. Likewise, Kudela (1984) and KuziemskaGrzeczka (1984) observed higher numbers of H. abietis in stumps and trap logs situated on clearcuts than under stand crowns. Fossestøl and Sverdrup-Thygeson (2009) considered that rather small differences in stump placement could have a strong effect on the composition of beetles that are attracted to the decaying wood. This may explain the different results obtained by the authors that were mentioned above.

The interaction between altitude and mountainside exposure had an effect on the number of Curculionidae (excl. Scolytinae) in the observed stumps, even though the significant effect of mountainside exposure, when analysed separately, was not statistically significant. The interaction effect was evident in the stumps at 600-700 $\mathrm{m}$ a.s.l., where the number of weevils was higher in the stumps on the mountainsides with a northern exposure compared with the stumps on the mountainsides with a southern exposure. It is assumed that stumps that are situated at lower altitudes a.s.l. and on different mountainsides have a greater difference in humidity than stumps that are located at higher altitudes, where there is the drying effect of wind. It is possible that the reduced sun exposure leading to increased-humidity stumps located at lower altitudes on the northern mountainsides was one of the reasons for their more intensive colonisation by Curculionidae (excl. Scolytinae) (Starzyk and Sek 1983).

The altitude a.s.l. was indicated to have an effect on Scolytinae found in the stumps. The stumps located at 900-1000 m a.s.l. were colonised much more abun- 
dantly by these insects when compared with those at 600-700 m a.s.1. However, Grodzki (2007), who investigated the effects of altitude on catchments of $I$. typographus in pheromone-baited traps situated in the Carpathian Mts., reported different results. The author observed greater numbers caught in the traps situated at the elevation of $800 \mathrm{~m}$ a.s.l. when compared with the traps situated at higher altitudes (800-1100 m a.s.l.). However, the author indicated that the relationship observed was not strong. The explanation may be related to the effect of weather or climate change on bark beetles dispersal. Faccoli (2009) found that summer drought associated with high temperatures can lead to the more intensive migration of I. typographus to the weakened trees in mountains. In North America it was observed that bark beetle populations can be influenced indirectly by the effects of climate on host-tree vigor which can result in a movement of bark beetles to higher altitudes (Bentz et al. 2010; Caroll et al. 2003).

Mountainside exposure had no effect on the number of Scolytinae in the stumps. Although more specimens were found in the stumps with a southern exposure, no differences with the stumps with a northern exposure were detected by the statistical tests used. The results obtained in the present study indirectly support the results of Grodzki (2007), who compared I. typographus pheromone trap catchments in the Bieszczady, Gorce and Tatra Mts. (Poland). The author observed higher catchments in the traps located on mountainsides with southern and eastern exposures when compared with mountainsides with northern and western exposures. The results of the present study showed significant effects of the interaction between altitude and mountainside exposure on the number of Scolytinae in the stumps that were observed. Scolytinae preferred $P$. abies stumps located at higher altitudes and with a sunny exposure where there were the best conditions for their development.

The comparison of insect numbers of less abundantly represented families observed in the stumps indicated that insects in this group were not affected by either stump altitude or mountainside exposure. However, low numbers of collected specimens in this group could be a reason for the results that were obtained when statistical tests were applied.

This study showed for the first time the changes in the abundance of insects in $P$. abies stumps depending on their location in mountain conditions. In many cases, the explanation of observed dependencies was based only on assumptions, and for that reason, these topics require further research.

\section{Conclusions}

Picea abies stumps located in the Eastern Sudety Mts. were colonised by insects from 18 families in 2 orders. The order Coleoptera was the most abundantly represented ( $97 \%$ of all collected entomofauna). The family Cerambycidae and Curculionidae, including the subfamily Scolytinae, were the most abundant with regard to insect numbers. Other families were considerably less numerous. In this group, the majority of specimens belonged to Elateridae, Muscidae and Rhagionidae.

The location of stumps a.s.l. affected the total number of insects colonising them. The stumps in clearcuts established at an altitude of 900-1000 m a.s.l. were colonised by insects to the greatest extent compared with those at the altitude $600-700 \mathrm{~m}$ a.s.l. The mountainsides on which the stumps were located also influenced the total number of insects in the $P$. abies stumps. More insects were found in the stumps on northern mountainsides, where less sunlight availability led to the increase in stump colonisation. The interaction effect between the altitude and mountainside exposure showed that the highest frequency of insects was recorded in the stumps at an altitude of 900-1000 m, regardless of mountainside exposure.

The number of Cerambycidae in P. abies stumps was influenced only by mountainside exposure and resulted in the highest frequency of this family in stumps located on northern mountainsides. Altitude a.s.l. was the most important factor influencing stump colonisation by Curculionidae (excl. Scolytinae), which preferred the stumps situated at higher altitudes. The location of stumps in the mountains had no effect on the numbers of the other insects that were observed.

\section{ACKnOWledgements}

The authors would like to thank Barbara Głowacka for guidance and assistance in carrying out in this research. 


\section{References}

Abrahamsson, M., Lindbladh, M. 2006. A comparison of saproxylic beetle occurrence between man-made high- and low-stumps of spruce (Picea abies). Forest Ecology and Management, 226, 230-237. DOI: 10.1016/j.foreco.2006.01.046

Abrahamsson, M., Lindbladh, M., Rönnberg, J. 2008. Influence of butt rot on beetle diversity in artificially created high-stumps of Norway spruce. Forest Ecology and Management, 255, 3396-3403. DOI: 10.1016/j.foreco.2008.01.010

Bake, A., Lekander, B. 1965. Studies on Hylobius abietis L. II. The influence of exposure on the development and production of Hylobius abietis, illustrated through one Norwegian and one Swedish experiment. Meddeleser fra det Norske Skogsforsøksvesen, 20, 117-135.

Bejer-Petersen, B. 1975. Length of development and survival of Hylobius abietis as influenced by silvicultural exposure to sunlight. Arsskrift - den Kongelige Veterinaer og Landbohojskole, 111-120.

Bentz, B.J. et al. 2010. Climate change and bark beetles of the Western United States and Canada: direct and indirect effects. BioScience, 60, 602-613. DOI: 10.1525/bio.2010.60.8.6

Brown, V.K., Gange, A.C. 1990. Insect herbivory below ground. Advances in Ecological Research, 20, 1-58. DOI: 10.1016/S0065-2504(08)60052-5

Cameron, A.C., Trivedi, P.K. 1998. Regression analysis of count data. Cambridge University Press, United Kingdom.

Caroll, A.L., Taylor, S.W., Régnière, J., Safranyik, L. 2003. Effects of climate change on range expansion by the mountain pine beetle in British Columbia. In: Mountain Pine Beetle Symposium: Challenges and Solutions (eds.: T.L. Shore, J.E. Brooks, J.E. Stone). Canadian Forest Service, Victoria, British Columbia, Information Report BCX-399, 223-231.

Coulson, S.J. et al. 1995. Thermal environments of Arctic soil organisms during winter. Arctic and Alpine Research, 27, 364-370. DOI: 10.1080/00040851.1995.12003133

Day, K.R, Nordlander, G., Kenis, M., Halldorson, G. 2004. General biology and life cycles of bark weevils. In: Bark and wood boring insects in living trees in Europe, a synthesis (eds.: F. Lieutier, K.R. Day, J.-C. Grégoire, H.F. Evans). Springer, Germany, 331-350.

Elton, E.T.G., Blankwaardt, H.F.H., Burger, H.C., Steemers, W.F., Tichelman, L.G. 1964. Insect communities in barked and unbarked pine stumps, with special reference to the large pine weevil (Hylobius abietis L., Col., Curculionidae). Journal of Applied Entomology, 1, 1-54. DOI: 10.1111/j.14390418.1964.tb02961.x

Evans, H.F., Moraal, L.G., Pajares, J.A. 2004. Biology, ecology and economic importance of Buprestidae and Cerambycidae. In: Bark and wood boring insects in living trees in Europe, a synthesis (eds.: F. Lieutier, K.R. Day, J.-C. Grégoire, H.F. Evans). Springer, Germany, 447-474.

Faccoli, M. 2009. Effect of weather on Ips typographus (Coleoptera Curculionidae) phenology, voltinism, and associated spruce mortality in the Southeastern Alps. Environmental Entomology, 38, 307-316. DOI: $10.1603 / 022.038 .0202$

Fossestøl, K.O., Sverdrup-Thygeson, A. 2009. Saproxylic beetles in high stumps and residual downed wood on clear-cuts and in forest edges. Scandinavian Journal of Forest Research, 24, 403-416. DOI: $10.1080 / 02827580903143871$

Gibson, K. et al. 2008. Mountain pine beetle impacts in high-elevation five-needle pines: current trends and challenges. USDA Forest Service Forest Health Protection, R1-08-020.

Grodzki, W. 2007. The use of pheromone traps for the monitoring of Ips typographus (L.) populations in selected national parks in the Carpathians. Prace Instytutu Badawczego Leśnictwa. Rozprawy i Monografie, 8, 1-127.

Hodkinson, I.D. 2005.Terrestrial insects along elevation gradients: species and community responses to altitude. Biological Reviews, 80, 489-513. DOI: 10.1017/S1464793105006767

Hoiss, B., Krauss, J., Potts, S.G., Roberts, S., SteffanDewenter, I. 2012. Altitude acts as an environmental filter on phylogenetic composition, traits and diversity in bee communities. Proceedings of Royal Society, B, 279, 4447-4456. DOI: 10.1098/ rspb.2012.1581

Idris, A.B., Nor, S.Md., Rohaida, R. 2002. Study on diversity of insect communities at different altitudes 
of Gunung Nuang in Selangor, Malaysia. Journal of Biological Sciences, 2, 505-507.

Jonsell, M., Schroeder, M., Weslien, J. 2005. Saproxylic beetles in high stumps of spruce: Fungal flora important for determining the species composition. Scandinavian Journal of Forest Research, 20, 54-62. DOI: 10.1080/02827580510008211

Jonsell, M., Weslien, J., Ehnoström, B. 1998. Substrate requirements for red listed saproxylic invertebrates in Sweden. Biodiversity and Conservation, 7, 749-764.

Kosibowicz, M. 1987. Insects in spruce stumps in Forest District Węgierska Górka in Beskidy mountains. Master Thesis, Agricultural Academy in Cracow, Poland.

Kronfuss, H., Havranek, W.M. 1999. Effects of elevation and wind on the growth of Pinus cembra L. in a subalpine afforestation. Phyton, 39, 99-106.

Kudela, M. 1984. Influence of site temperature conditions on large pine weevil (Hylobius abietis L.) population density. Sbornik Ústavu Aplikované Ekologie a Ekotechniky Vysoké, 1, 129-148.

Kuziemska-Grzeczka, G. 1984. Studies on the development of the large pine weevil (Hylobius abietis L.) (Col., Curculionidae) in different species of trees on sunny and shaded area (in Polish). Folia Forestalia Polonica, Seria A-Leśnictwo, 27, 49-57.

Långström, B., Hellqvist, C. 1985. Pinus contorta as a potential host for Tomicus piniperda L. and T. minor (Hart.) (Col., Scolytinae) in Sweden. Zeitschrift Angewandte Entomologie, 99, 174-181.

Leather, S.R., Day, K.R., Salisbury, A.N. 1999. The biology and ecology of the large pine weevil, Hylobius abietis (Coleoptera; Curculionidae): a problem of dispersal. Bulletin of Entomological Research, 89, 3-16. DOI: 10.1017/S0007485399000024

Lindbladh, M., Abrahamsson, M. 2008. Beetle diversity in high-stumps from Norway spruce thinnings. Scandinavian Journal of Forest Research, 23, 339-347. DOI: 10.1080/02827580802282762

Lindelöw, Å., Eidmann, H.H., Nordenhem, H. 1993. Response of the ground of bark beetle and weevil species colonizing conifer stumps and roots to terpenes and ethanol. Journal of Chemical Ecology, 19, 1393-1403.

Lindhe, A., Lindelöw, Å. 2004. Cut high stumps of spruce, birch, aspen and oak as breeding substrates for saproxylic beetles. Forest Ecology and Management, 203, 1-20. DOI: 10.1016/j. foreco.2004.07.047

Littell, R.C., Stroup, W.W., Freund, R.J. 2002. SAS for linear models. SAS Institute Inc., Cary, NC.

Małachowska, J. et al. 2007. Forest monitoring - assessment of forest condition in Poland in 1991-2005. Environmental Monitoring Library, Poland.

McCullagh, P., Nelder, J.A. 1989. Generalized linear models. Chapman and Hall, London.

McLean, I.F.G. 2000. Beneficial Diptera and their role in decomposition. Contributions to a Manual of Palaearctic Diptera, Volume 1 (eds.: L. Papp, B. Darvas). Science Herald, Budapest, 491-517.

Miller, D.R. 2006. Ethanol and (-)-a-pinene: attractant kairomones for some large wood-boring beetles in southeastern USA. Journal of Chemical Ecology, 32, 779-794. DOI: 10.1007/s10886-006-9037-8

Montgomery, M.E., Wargo, P.M. 1983. Ethanol and other host-derived volatiles as attractants to beetles that bore into hardwoods. Journal of Chemical Ecology, 9, 181-190.

Nelder, J.A., Weddenburn, R.W.M. 1972. Generalized linear models. Journal of the Royal Statistical Society, Series A, 135, 370-384.

Oleksyn, J.J. et al. 1998. Growth and physiology of Picea abies populations from elevational transects: common garden evidence for altitudinal ecotypes and cold adaptation. Functional Ecology, 12, 573-590. DOI: 10.1046/j.1365-2435.1998.00236.x

Rotheray, G.E. et al. 2001. The biodiversity and conservation of saproxylic Diptera in Scotland. Journal of Insect Conservation, 5, 77-85.

Safranyik, L., Linton, D.A. 1999. Spruce beetle (Coleoptera: Scolytidae) survival in stumps and windfall. Canadian Entomologist, 131, 107-113. DOI: 10.4039/Ent131107-1

SAS Institute Inc. 2008. SAS/STAT ${ }^{\circledR} 9.2$ User's Guide. SAS Institute Inc. Cary, NC.

Sauvard, D. 2004. General biology of bark beetles. In: Bark and wood boring insects in living trees in Europe, a synthesis (eds.: F. Lieutier, K.R. Day, J.-C. Grégoire, H.F. Evans). Springer, Germany, 63-38.

Schlyter, F. 2004. Semiochemicals in the life of bark feeding weevils. In: Bark and wood boring insects in living trees in Europe, a synthesis (eds.: F. Lieut- 
ier, K.R. Day, J.-C. Grégoire, H.F. Evans). Springer, Germany, 351-364.

Schroeder, L.M., Lindelöw, Å. 2002. Attacks on living spruce trees by the bark beetle Ips typographus (Col. Scolytidae) following a storm-felling: a comparison between stands with and without removal of wind-felled trees. Agricultural and Forest Entomology, 4, 47-56. DOI: 10.1046/j.14619563.2002.00122.x

Schroeder, L.M., Weslien, J., Lindelöw, Å., Lindhe, A. 1999. Attacks by bark- and wood-boring Coleoptera on mechanically created high stumps of Norway spruce in the two years following cutting. Forest Ecology and Management, 123, 21-30. DOI: 10.1016/S0378-1127(99)00013-4

Skrzecz, I. 1996. Impact of Phlebia gigantea (Fr.: Fr) Donk on the colonization of Scots pine stumps ( $P i$ nus sylvestris L.) by the large pine weevil (Hylobius abietis L.). Folia Forestalia Polonica, Series A - Forestry, 38, 89-101.

Skrzecz, I. 2001. Large pine weevil (Hylobius abietis L.) abundance and the extent of damage in plantations established on clearcuts with pine stumps treated with the fungus Phlebiopsis gigantea (Fr.: Fr.) Jülich. Folia Forestalia Polonica, Series A - Forestry, 43, 137-151.

Starzyk, J.R. 1977. The influence of insolation of the stand upon the appearance of the timber beetles (Col. Cerambycidae) in the Niepolomice Forest. Sylwan, 6, 41-48.
Starzyk, J.R., Brawer, M., Dajek, S. 1991. Longhorn beetles (Coleoptera: Cerambycidae) in Gorce National Park. Parki Narodowe i Rezerwaty Przyrody, 10, 61-78.

Starzyk, J.R., Sęk, A. 1983. Communities and associations of insects in Norway spruce stumps on the selected areas of the Forest Experimental Station at Krynica (the Beskid Sadecki Mts.). Acta Agraria et Silvatica, Series Silvestris, 22, 73-86.

Starzyk, J.R., Szafraniec, S. 1989. Longhorn beetles (Coleoptera, Cerambycidae) of Babia Góra National Park (western Carpathians). Zeszyty Naukowe AR Kraków, Leśnictwo, 19, 127-148.

Stokes, M.E., Davies, C.S., Koch, G.G. 2000. Categorical data analysis using the SAS system. 2nd ed. SAS Institute Inc., Cary, NC.

Von Sydow, F., Birgersson, G. 1997. Conifer stump condition and pine weevil (Hylobius abietis) reproduction. Canadian Journal Forest Research, 27, 1254-1262. DOI: 10.1139/x97-089

Wallace, H.R. 1953. The ecology of the insect fauna of pine stumps. Journal of Animal Ecology, 22, 154-171.

Weiss, S.B., Murphy, D.D., White, R.R. 1988. Sun, slope, and butterflies: topographic determinants of habitat quality for Euphydryas editha. Ecology, 69, 1486-1496.

Wiąckowski, S. 1957. Insects in pine stumps depending on the age and size of the stump. Ekologia Polska, $3,13-123$. 